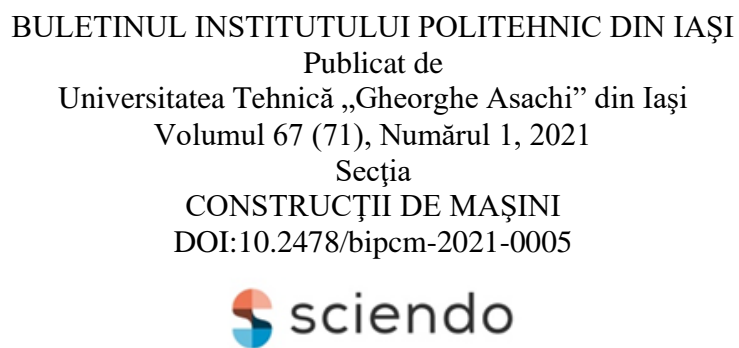

\title{
ASPECTS REGARDING THE DYNAMIC BEHAVIOR OF A HYDRAULIC CYLINDER
}

\author{
BY
}

\author{
IRINA MARDARE*, IRINA TIȚA and ALEXANDRU CONSTANTIN ZAHARIA \\ "Gheorghe Asachi" Technical University of Iaşi, \\ Department of Fluid Mechanics, Fluid Machinery and Fluid Power Systems
}

Received: January 21, 2021

Accepted for publication: March 12, 2021

\begin{abstract}
This paper deals with hydraulic cylinders with and without end position cushioning. The reduction of the velocity at the end of the stroke is important in order to preserve the structural integrity and to avoid undesirable motion of the load. The mathematical model of such a hydraulic cylinder is shown, as well as the Matlab functional diagram for the system. It is also revealed the role of the working fluid, considering the actual recommendations regarding the biodegradable substances. It was considered both mineral base liquids and vegetable base liquids. The functional diagram offers the possibility to view for the hydraulic system the variation of the speed, flow rate, rate and stroke of the piston, in both cases: with and without end position cushioning. Is also shown a CFD analysis of fluid flow through the supply/outlet connections of the hydraulic cylinder.
\end{abstract}

Keywords: hydraulic cylinder; end position cushioning; biodegradable hydraulic fluids; mineral hydraulic fluids; simulation.

\section{Introduction}

In fluid power systems, double acting cylinders are frequently used in various types of systems. Considering this, there are some studies containing

${ }^{*}$ Corresponding author; e-mail: irina.mardare@academic.tuiasi.ro (C) 2021 Irina Mardare et al.

This is an open access article licensed under the Creative Commons Attribution-NonCommercialNoDerivatives 4.0 International License (CC BY-NC-ND 4.0). 
relevant analysis having in view increasing efficiency, or finding simpler and more efficient solutions for the systems in which they operate.

In a review regarding the pump control of double acting hydraulic cylinders, Ketelsen and workfellows (Ketelsen et al., 2019) present the identified solutions used to increase energy efficiency: by replacing servovalve with on/off valves (Heybroek et al., 2012), by using Multiple Pressure Lines, by using hydraulic transformers (Achten, 1999) or by controlling the pump flow rate (Rose and Ivantysynova, 2011).

Other studies consider the effect of friction on the behavior of hydraulic cylinders, which are tested for various materials and different loads (Tran et al., 2010; Yananda and Sekikava, 2008; Tran et al., 2012).

Regarding the end position cushioning, different ways to reduce piston speed are studied. In (Schwartz et al., 2005) one can see a study on dynamic self-regulating brake. It was used tapered bushings mounted on both sides of the piston, or grooves, varying in number and design, which are important for the control of the passage section to the connections of the hydraulic cylinder (Algar et al., 2021). Another study, developed by Algar and collaborators, reveals the radial forces caused by the movement of the piston between the cylinder connections. The study shows the importance of the number and distribution of the piston perimeter grooves in cushioning performance (Algar $e t$ al., 2017).

An important element in the operation of the hydraulic systems with cylinders and the cylinder itself is the type of working fluid. Studies on liquids based on natural esters (Mendoza et al., 2011; Botz, 2011; Paeglis et al., 2009), show that although vegetable-based oils can only be used with additives, to achieve the quality of the mineral based liquids, this increases costs. However, they are preferred in the applications which require that environmental protection standards are keept.

The paper presents the first part of a study on simulating a system with double acting hydraulic cylinder, with and without end position cushioning. The analysis consider the compare between the case in which as a transmission fluidis used a mineral oil and the one in which a biodegradable oil is used. In thefirst section of the work, the simulation is developed for a system with a symmetric cylinder,with and without end position cushioning,following that in the second section to be analysed a system with differential cylinder, with and without end position cushioning. At the end, some conclusions regarding the comparison between the two cases considered will result and especially some conclusions regarding the use of biodegradable oils are of interest.

The present paper is organized in four sections and conclusions. A section in which is presented the mathematical model, a section in which is presented the simulation diagram, a section in which are presented the results of simulation anda section including some CFD analysis aspects on the variation in the field of pressure and speed at the hydraulic cylinder connections. 


\section{Mathematical Model}

The double acting hydraulic cylinder, without end position cushioning, receives the Qa flow from the hydraulic pump. On active surfaces of the piston, $A_{1}$ and $A_{2}$ (Fig. 1), will act pressure forces depending on supply pressure and return line pressure respectively (Zhang, 1999).

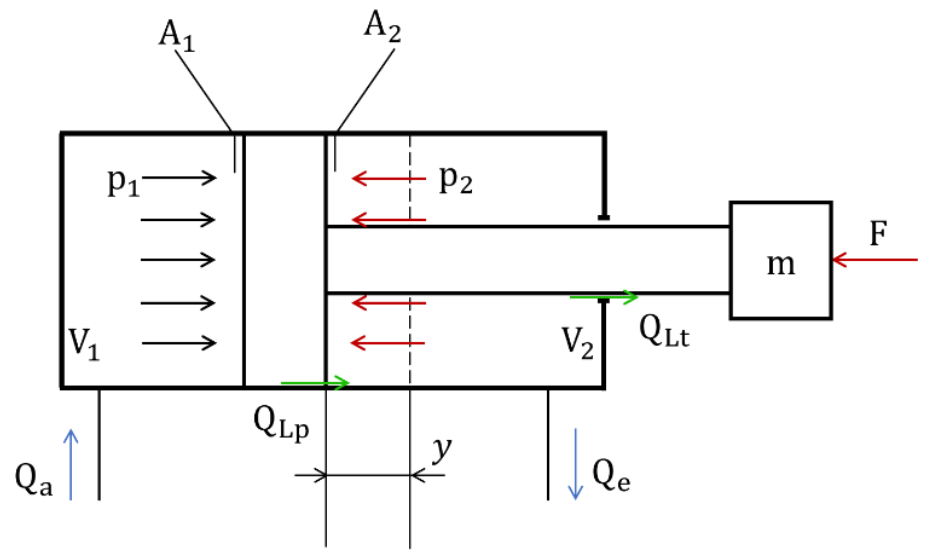

Fig. 1 - Definition of variables used for cylinder model.

Considering the notations în Fig. 1, the force balance on the mobile assembly may be described as:

$$
p_{1} \cdot A_{1}-p_{2} \cdot A_{2}=m \frac{d^{2} y}{d t^{2}}+c \frac{d y}{d t}+k y+F
$$

where $p_{1}$ is the supply pressure, $p_{2}$ - the return line pressure, $A_{1}$ - the piston area, $A_{2}$ - the rod side area, $m$ - the mobile assembly mass, $y$ - the piston position, $F$ - the external and Coulomb friction force, $c$ - the viscous friction coefficient, $k$ - the equivalent spring constant of the mechanical structure.

Using the continuity equation flows in and from cylinder chambers are:

$$
\begin{gathered}
Q_{a}=A_{1} \cdot v+\frac{V_{1}}{\beta} \cdot \frac{d p_{1}}{d t}+Q_{L p} \\
Q_{e}=A_{2} \cdot v-\frac{V_{2}}{\beta} \cdot \frac{d p_{2}}{d t}+Q_{L p}-Q_{L t}
\end{gathered}
$$

where $Q_{a}$ is the supply flow-rate, $Q_{e}$ - the return line flow-rate, $V_{1}$ - the volume of the chamber without the rod, $V_{2}$ - the volume of the rod chamber, $\beta$ - the 
effective bulk modulus, $\mathrm{Q}_{\mathrm{Lp}}$ and $\mathrm{Q}_{\mathrm{Lt}}$ - the internal and external leakage flow rate respectively.

\section{Functional Diagram}

Functional diagram Matlab/Simulink contains the components correponding to equipment in the hydraulic diagram.

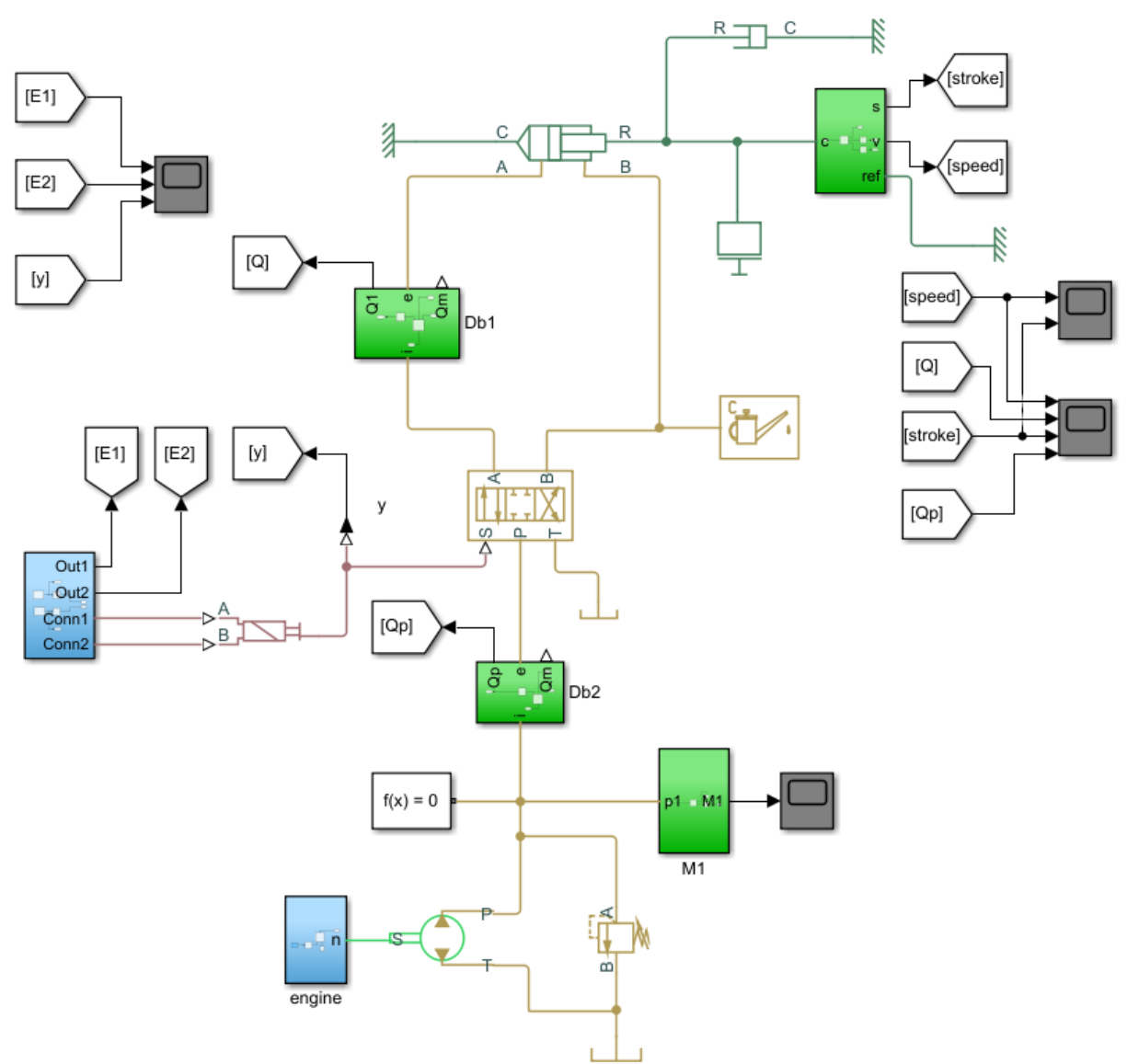

Fig. 2 - Matlab/Simulink functional diagram, without end position cushioning.

Functional diagram offers, on four scopes, information about: valve actuation law, pressure at the pump, pozition and speed of the rod and flow on left line.

In Fig. 3 is illustrated the actuation law for the directional control valve. It is also possible to change the value for the rotational speed at the pump axle. It may be a constant value or a variable one accordig to a law from a signal builder configuration. 
In fluid power sistem, the variation of temperature has as consequence the variation of liquid viscosity and as a result modification of working performances (Tiţa et al., 2017).

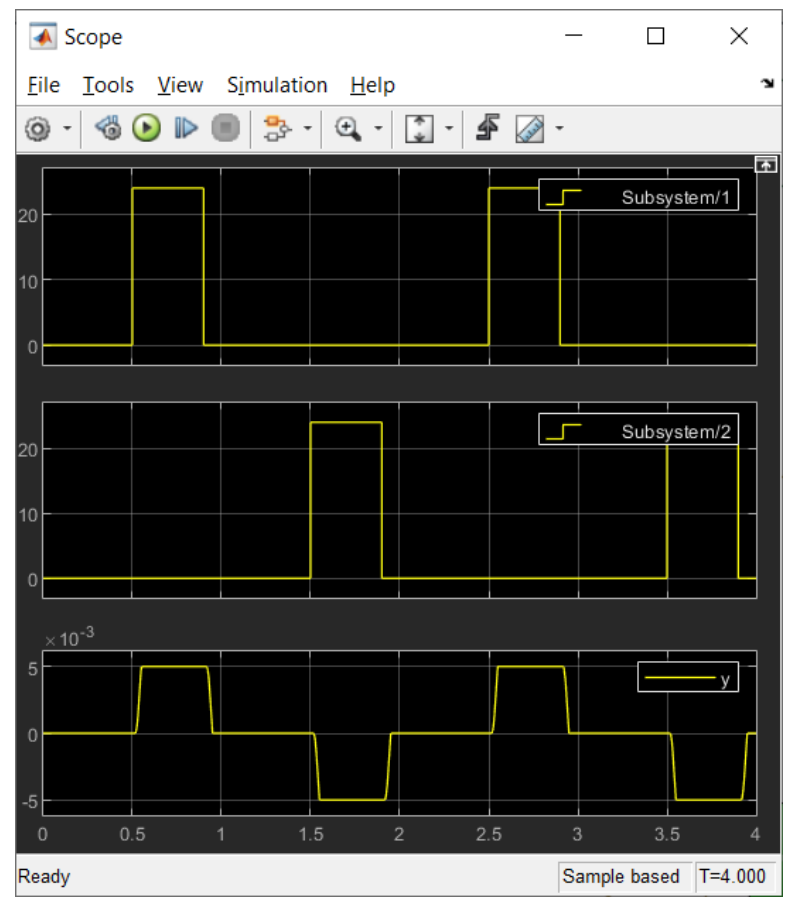

Fig. 3 - Actuation law for the directional control valve.

Matlab/Simulink offers two blocks possible to be used: Custom hydraulic fluid block, which enables to set the values of the properties of the oil used, and the Hydraulic fluid block, that provides a library of liquids for which the properties are already set (Fig. 4).

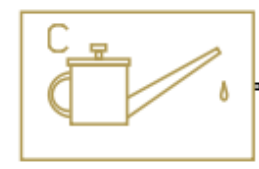

Custom Hydraulic Fluid

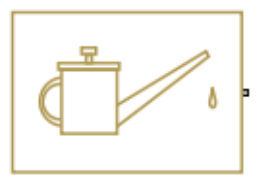

Hydraulic Fluid

Fig. 4 - Hydraulic fluid blocks.

As a transmission medium for hydraulic power both mineral oil based liquids and natural esters based oils are used. Their characteristics may be introduced in the dialog box of the Custom hydraulic fluid block. 


\section{Results}

In the Custom hydraulic fluid blockthere was used the parameters of the ISO VG 46 and the results are shown in Fig. 5.

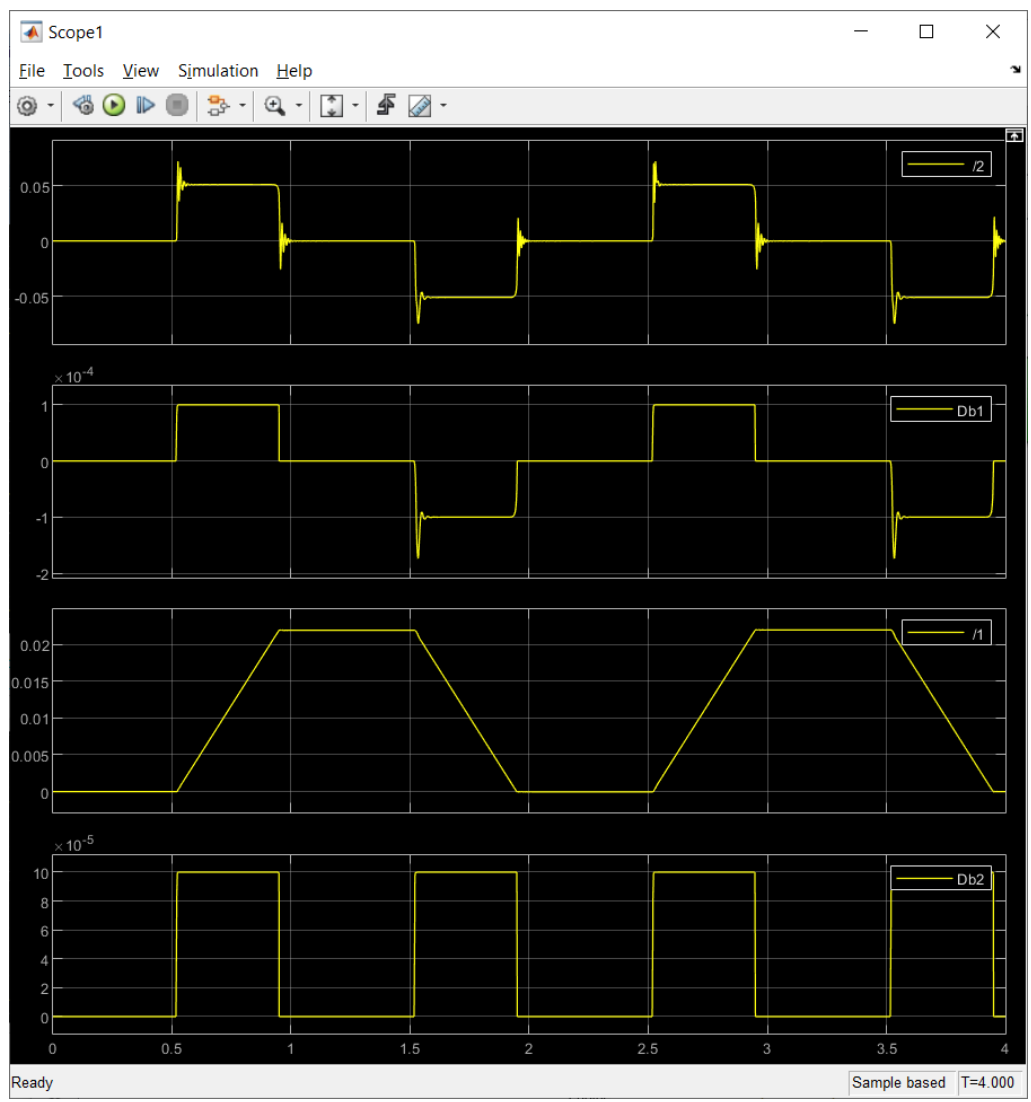

Fig. 5 - Results using ashydraulic fluid ISO VG 46.

It is known that, for a satisfactory work of the hydraulic system, viscosity must be medium. High viscosity index VI is also necessary in order to ensure prevention of rubbing wear and external leakages.

Table 1

Parameters of Hydraulic Fluid

\begin{tabular}{||c|c|c|c|}
\hline Parameter & U.M & ISO VG 46 & $\begin{array}{c}\text { Hydraway BIO SE } \\
32-68\end{array}$ \\
\hline \hline Density & $\mathrm{kg} / \mathrm{m}^{3}$ & 867.346 & 915 \\
\hline Kinematic viscosity at $40^{\circ} \mathrm{C}$ & $\mathrm{cSt}$ & 45.733 & 37.430 \\
\hline VI & & 185 & 168.44 \\
\hline Bulk modulus & $\mathrm{Pa}$ & $1.481 \cdot 10^{9}$ & $1.38 \cdot 10^{9}$ \\
\hline
\end{tabular}


For the case of Hydraway BIO SE 32-68 (Paeglis et al., 2009; www.rscbio.com; www.teresolve.com) some characteristics, required in block parameters hydraulic fluid, are specified in Table 1.
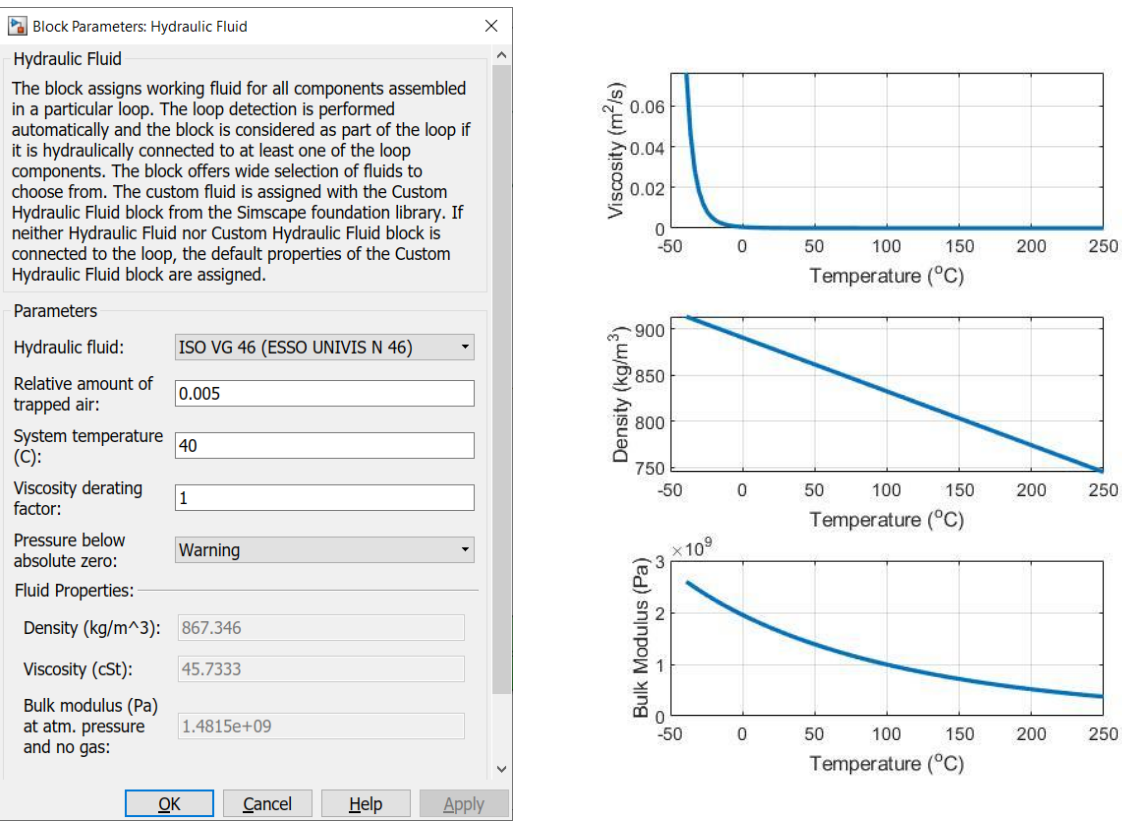

Fig. 6 - Bloc parameters and caracteristics for ISO VG 46.

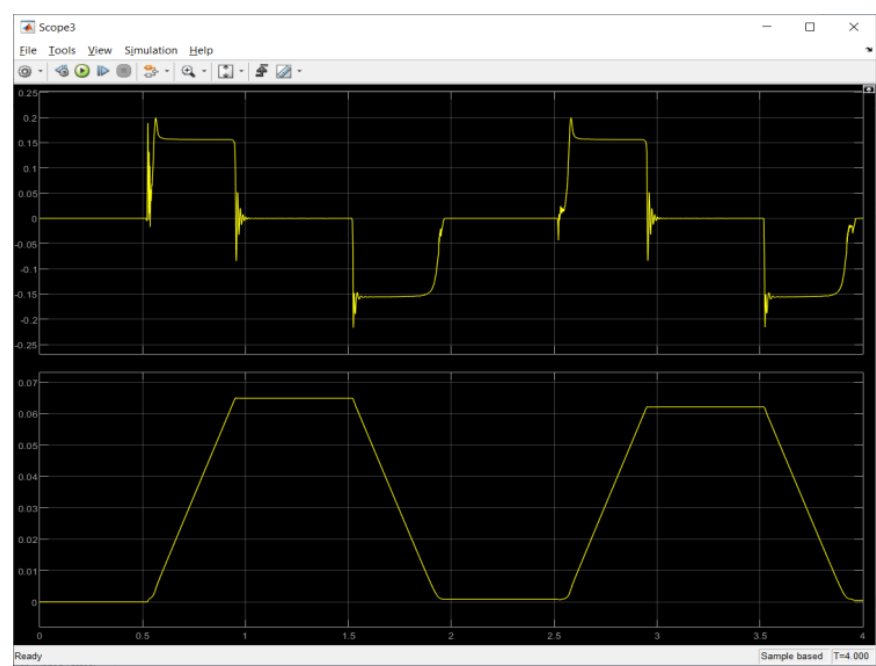

Fig. 7 - Velocity and position for the piston using as hydraulic fluid ISO VG 46 and end position cushioning. 
In Fig. 7 one can see velocity and piston position for the system with double acting cylinder and end position cushioning in Fig. 8.

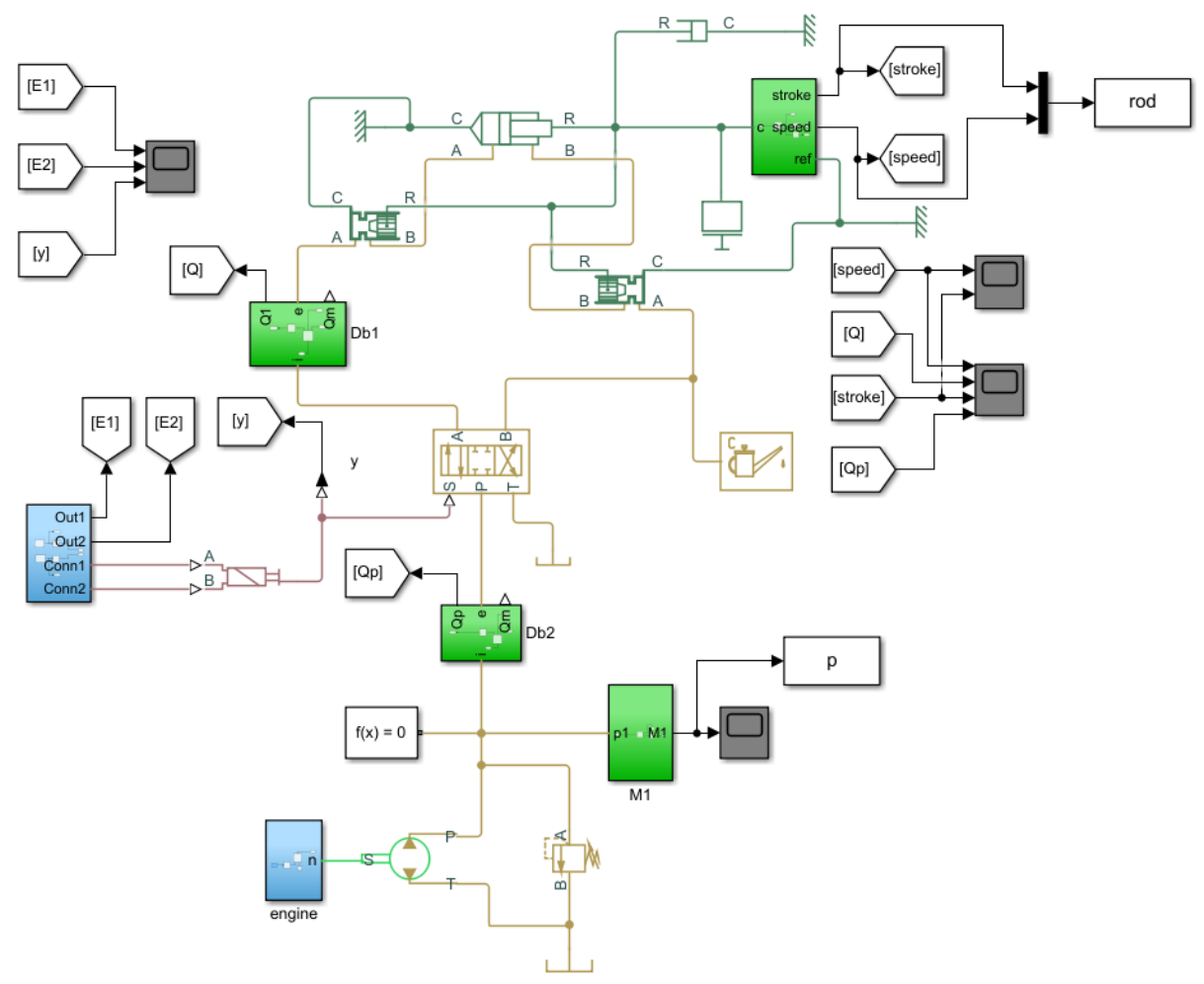

Fig. 8 - Matlab/Simulink functional diagram, with end position cushioning.

\section{CFD Analysis of Connections of the Cylinder}

CFD analysis regards flow rate and a pressure in the cylinder and its connections.

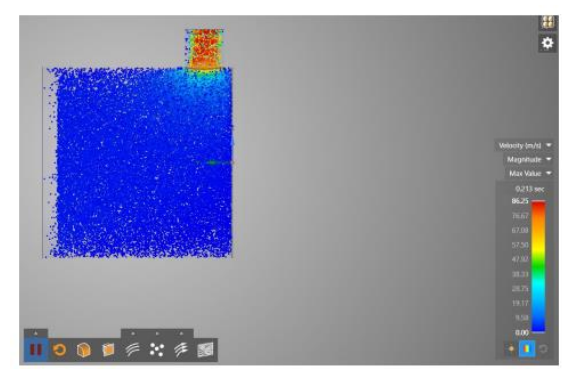

a. velocity repartition

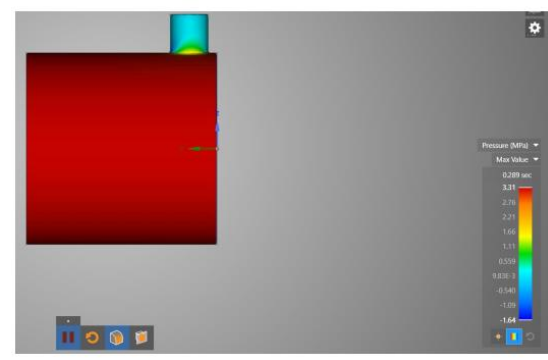

b. pressure repartition

Fig. 8 - Simulation for $2.5 \mathrm{~m} / \mathrm{s}$ speed of the fluid in connections. 


\section{Conclusions}

The paper presents some aspects regarding the reduction of the velocity at the end of the stroke for a hydraulic cylinder.

Although expensive because of the additives, vegetable ester-based oils they are increasingly being studied as hydraulic working fluid. Because they are biodegradable they are preferred, especially in applications in which environmental standards are mandatory.

Matlab/Simulink functional diagram presented in this paper is an instrument which permits the analysis of the influence of hydraulic fluid on system behaviour. It is also of importance to use end position cushioning in order to a better control of the piston movement.

CFD analysis reveals the possible low pressures areas and can be used to a better configuration of the cylinder connections in correlation with flow and pipes used in the system.

The dynamic behaviour of differential cylinders, with or without end position cushioning, shall be analysed for the continuation of the study, as well as the influence of biodegradable liquids parameters on their behaviour.

\section{REFERENCES}

Achten P.A.J., What a Difference a Hole Makes-The Commercial Value of the INNAS Hydraulic Transformer. In Proceedings of the Sixth Scandinavian International Conference on Fluid Power, Tampere, Finland, 26-28 May 1999, 873-886.

Algar A., Codina E., Freire J., Experimental Study of 3D Movement in Cushioning of Hydraulic Cilinder, Energies 2017, 10, 746, 7-19, doi: 103390/en10030746.

Algar A., Freire J., Castilla R., Codina E., Simulation of Hydraulic Cylinder Cushioning, Sustenability 2021, 13, 494, doi org/103390/su13020494.

Botz O., Vegetable Oil-Based Hydraulic Fluid and Transmision Fluid, Patent Application Publication, US 2011/0195885 A1.

Heybroek K., Vael G., Palmberg J.O., Towards Resistance-free Hydraulics in Construction Machinery, In Proceedings of the 8th International Fluid Power Conference, Dresden, Germany, 26-28 March 2012, 2, 123-138.

Ketelsen S., Padovani D., Andersen T.O., Ebbesen M. K. and Schmidt L., Classification and Review of Pump-Controlled Differential Cylinder Drives, Energies 2019, 12, 1293, doi: 103390/en 12071293.

Mendoza G., Igartua A., Fernandez-Diaz B., Urquiola F., Vivanco S., Arguizoniz Z., Vegetable Oils as Hydraulic Fluids for Agricultural Applications, Grasas y Aceites 62 (1), Enero-Marzo 29-38, 2011, doi: 103989/gya 056210.

Paeglis T., Karabeško P., Mieriņa I., Seržane R., Strēle M., Tupureina V., Jure M., Compositions of Hydraulic Fluids Based on Rapeseed Oil and its Derivatives, Engineering for Rural Development, Jelgava, 28-29.05.2009. 
Rose J., Ivantysynova M., A Study of Pump Control Systems for Smart Pumps, In Proceedings of the $52^{\text {nd }}$ National Conference on Fluid Power, Las Vegas, NV, USA, 23-25 March 2011; 683-692.

Schwartz C., de Negri V.J., Climaco V.J., Modeling and Analysis of an Auto-Ajustable Stroke and Cushioning Device for Hydraulic Cylinder, Journal of the Brazil Soc. of Mech. Sci and Eng., 27, 4, 415-426 (2005).

Tița I., Mardare I., Husaru E.D., Theoretical Aspects Concerning Working Fluids in Hydraulic Systems, MATEC Web of Conferences, 112, 07014 (2017), doi: 10.1051/matecconf/20171120701, IManE\&E 2017.

Tran X.B., Hafizah N., Yanada H., Modeling of Dynamic Friction Behaviors of Hydraulic Cylinder, Mechatronics, 22, 65-75 (2012).

Tran X.B., Matsui A., Yanada H., Effect of Viscosity and Type of Oil on Dynamic Behavior of Friction of Hydraulic Cylinder, Trans Jpn Fluid Power Syst.Soc. 41, 2, 28-35 (2010).

Yanada H., Sekikava Y., Modeling of Dynamic Behaviors of Friction, Mechatronics, 18, 7, 330-339 (2008).

Zhang Q., Hydraulic Linear Actuator Velocity Control Using a Feedforward-Plus-PID Control, International Journal of Flexible Automation and Integrated Manufacturing, 7, 3, 277-292 (1999).

www.rscbio.com (accessed on January 2021).

www.teresolve.com (accessed on January 2021).

\section{ASPECTE PRIVIND COMPORTAMENTUL DINAMIC AL CILINDRILOR HIDRAULICI}

\section{(Rezumat)}

Lucrarea are ca subiect simularea cilindrilor hidraulici cu şi fără frânare la capătul cursei. Este prezentat modelul matematic al cilindrului hidraulic, precum şi schema de simulare. În utilizarea acesteia s-a luat în considerare folosirea ca fluid de lucru, atât a lichidelor cu baza minerală, cât și a lichidelor cu baza vegetală. Rezultatele obținute, prezintă variația vitezei, a debitului de alimentare și a cursei realizate de pistonul cilindrului, pentru variantele $\mathrm{cu}$ şi fără franare la capatul cursei. Este prezentată, de asemenea şi analiza CFD a curgerii lichidului prin racordurile de alimentare/evacuare ale cilindrului hidraulic. 